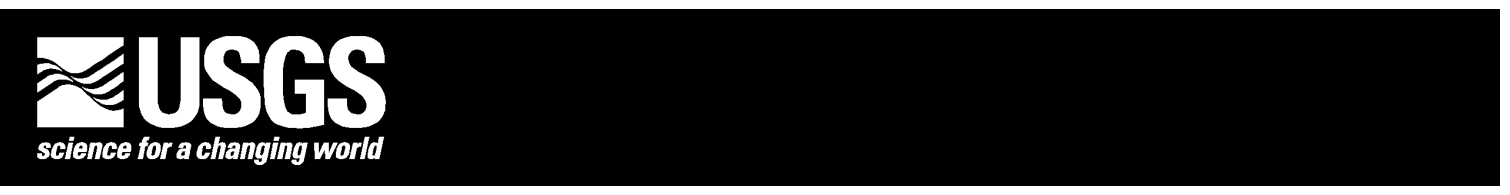

\title{
The Distribution of MVT-related Metals in Acid-insoluble Residues of Paleozoic Rocks in the Ozark Plateaus Region of the United States
}

by Lopaka Lee and Martin B. Goldhaber ${ }^{1}$

Open-File Report 01-0042

2001

Online Version 1.0

http://geology.cr.usgs.gov/pub/open-file-reports/ofr-01-0042/

This report is preliminary and has not been reviewed for conformity with U.S. Geological Survey editorial standards or with the North American Stratigraphic Code. Any use of trade, firm, or product names is for descriptive purposes only and does not imply endorsement by the U.S. Government.

\section{U.S. DEPARTMENT OF THE INTERIOR}

U.S. GEOLOGICAL SURVEY

${ }^{1}$ Denver, Colorado 


\section{TABLE OF CONTENTS}

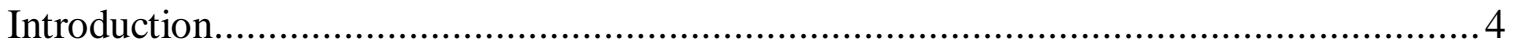

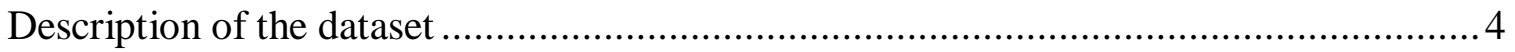

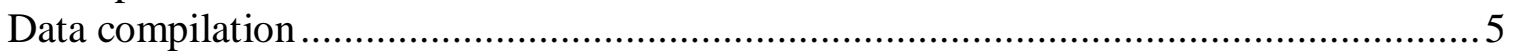

The spatial distribution of MVT-related metals IN rocks of the Ozark region ................. 8

Two-dimentional maps of the concentrations of metals in Ozark region rocks ................. 8

Interpretations of 2-D dimensional maps ....................................................... 8

Three-dimensional visualizations of the concentrations of metals in rocks of the central

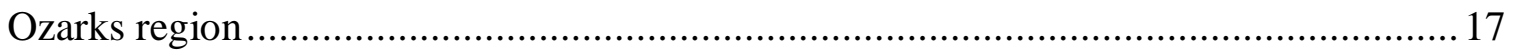

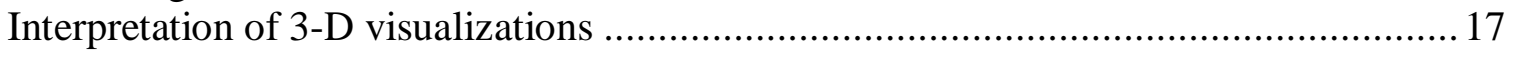

The statistical distribution of MVT-related metals in acid-insoluble residues of Ozark

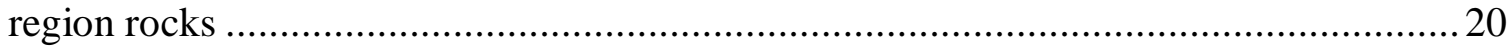

Concentration-detection frequency grids .............................................................. 20

Interpretation of the concentration-detection frequency grids................................. 21 


\section{LIST OF FIGURES}

Figure 1.0 The Ozark Plateaus physiographic province and location of CUSMAP

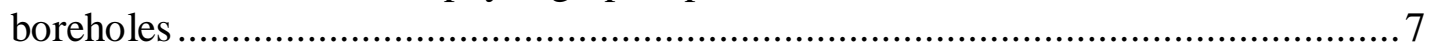

Figure 2.0 Plan-view distribution of As in acid-insoluble residues of rock samples......... 9

Figure 2.1 Plan-view distribution of $\mathrm{Cd}$ in acid-insoluble residues of rock samples ....... 10

Figure 2.2 Plan-view distribution of Co in acid-insoluble residues of rock samples ....... 11

Figure 2.3 Plan-view distribution of $\mathrm{Cr}$ in acid-insoluble residues of rock samples ........ 12

Figure 2.4 Plan-view distribution of $\mathrm{Cu}$ in acid-insoluble residues of rock samples ....... 13

Figure 2.5 Plan-view distribution of $\mathrm{Ni}$ in acid-insoluble residues of rock samples ........ 14

Figure 2.6 Plan-view distribution of $\mathrm{Pb}$ in acid-insoluble residues of rock samples........ 15

Figure 2.7 Plan-view distribution of $\mathrm{Zn}$ in acid-insoluble residues of rock samples....... 16

Figure 2.83 -D visualization of $\mathrm{Zn}$ distribution in the aquifer units of the central Ozarks

Figure $2.93-\mathrm{D}$ visualization of $\mathrm{Pb}$ distribution in the aquifer units of the central Ozarks

\section{LIST OF TABLES}

Table 1.0 Regional stratigraphy and hydrogeology of the Ozark Plateaus .................... 22

Table 1.1 Concentration-detection frequency grid for As .................................... 23

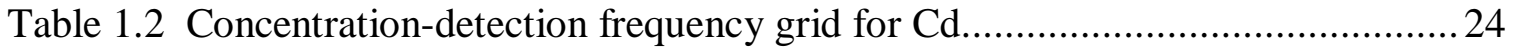

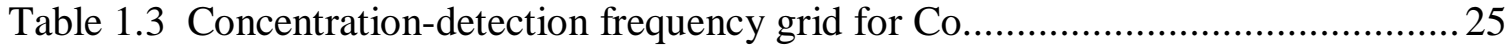

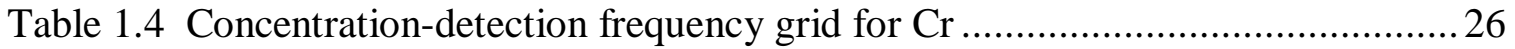

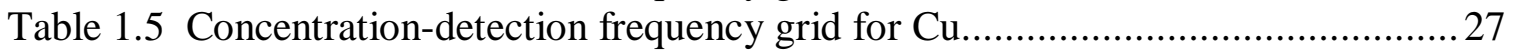

Table 1.6 Concentration-detection frequency grid for $\mathrm{Ni}$......................................28

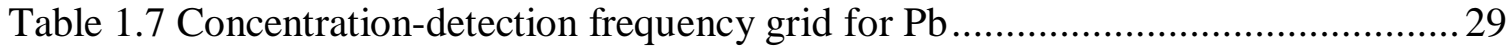

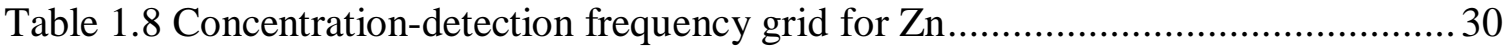




\title{
THE DISTRIBUTION OF MVT-RELATED METALS IN ACID-INSOLUBLE RESIDUES OF ROCKS IN THE OZARK PLATEAUS REGION OF THE UNITED STATES
}

\author{
by Lopaka Lee and Martin B. Goldhaber
}

\section{INTRODUCTION}

This report is a compilation of figures and tables that show the spatial and statistical distribution of elemental concentrations of $\mathrm{As}, \mathrm{Cd}, \mathrm{Co}, \mathrm{Cu}, \mathrm{Cr}, \mathrm{Ni}, \mathrm{Pb}$, and $\mathrm{Zn}$ in acidinsoluble residues of rocks from the Ozark Plateaus region of the United States.

The figures and graphs of this report are based on a database that contains over 17,500 rock samples from 285 different boreholes scattered throughout the Ozark region. Collectively, this dataset contains samples representative of almost every Paleozoic rock unit in the Ozark region.

This report is part of a USGS parent project that is focused on characterizing the effects of MVT mineralization on the background groundwater chemistry of the Ozark Plateaus region of the United States (Lee, 2000). The first phase of the parent study involved the investigation of spatial and statistical relationships between MVT-related metals in rocks and groundwater. The figures and tables of this report are centered on characterizing, on a regional level, the spatial and statistical distribution of MVT-related metals in aquifer rocks. A companion open-file report that shows the spatial and statistical distribution of MVT-related metals in groundwater of the Ozark region is concurrently being published under the title The distribution of dissolved MVT-related metals in groundwater of the Ozark Plateaus region of the United States.

A minimal amount of interpretations of the figures and tables of this report are provided within the text. A detailed interpretation of this data, as it relates to the effects of MVT mineralization on the natural-background groundwater chemistry of the Ozark region, is available in available in Lee (2000).

The scope of this report is regional. Summaries of this report's dataset that focus on local-scale variations, such as metal variation along individual borehole lengths, are included in other USGS reports (Erickson and others 1978a, 1981, 1985, 1988a, 1990).

\section{DESCRIPTION OF THE DATASET}

The dataset that this report is based upon was generated during the USGS Conterminous U.S. Mineral Assessment Program (CUSMAP) of the Ozark region. This program evaluated the mineral resource potential of selected $1 \times 2$ degree quadrangles within the Ozarks (Erickson and others 1978b, 1988b, 1991). 
A sub-project of the CUSMAP program was centered on identifying MVTmineralizing fluid pathways, and highly mineralized ground throughout the Ozark region (Erickson and others 1978b). The primary research approach of this project was to chemically isolate and analyze the acid $(\mathrm{HCl})$-insoluble residues of borehole rock samples. The acid-insoluble residues of rocks were isolated and analyzed because MVT sulfides, and therefore MVT-related metals are concentrated within this rock fraction (Erickson and others, 1981).

The rock samples from which the acid-insoluble residues are derived were obtained from boreholes distributed throughout the Ozarks (Figure 1.0). Individual rock samples are composites representative of every $10 \mathrm{ft}$ of borehole interval.

The chemical analyses performed on the insoluble residues are semi-quantitative, elemental-abundance analyses. Thirty-two chemical elements were determined using a DC-arc spectrometer (Grimes and Marranzino, 1968). Elemental concentrations are reported as classed values in six steps per order of magnitude $(1,0.7,0.5,0.3,0.2$, and $0.15)$. Thus, elemental determinations can have values of $3,5,7,10,15,20, \ldots$ parts permillion (ppm). Concentration determinations range from 3 to 20,000 ppm, with specific element ranges and detection limits set to encompass distributions typical to the region.

The precision of the chemical determinations is within one adjoining step on each side of the reported value 83 percent of the time, and within two adjoining steps on each side of the reported value 96 percent of the time (Grimes and Marranzino, 1968).

The CUSMAP data used in this report were obtained from the USGS National Geochemical Database.

\section{DATA COMPILATION}

This report utilizes 17,703 acid-insoluble residues of rock samples from 285 different boreholes of the original CUSMAP dataset. Most of these boreholes are contained within the Joplin, Springfield, Harrison, and Rolla 1 by 2 degree quadrangles (Figure $1.0)$.

Eight MVT-related metals were chosen for investigation: arsenic (As), cadmium (Cd), chromium $(\mathrm{Cr})$, cobalt $(\mathrm{Co})$, copper $(\mathrm{Cu})$, nickel $(\mathrm{Ni})$, lead $(\mathrm{Pb})$, and zinc $(\mathrm{Zn})$. These elements were chosen because: 1) they represent a metal suite characteristic of MVT mineralization that differs from elements intrinsic to the lithology of the region, and 2) all were determined in both the rock and water chemical analyses used within the parent project with which this report is associated.

The data were compiled by first obtaining the digital records from the USGS National Geochemical Database and checking the dataset for data-entry errors. Latitudes and 
longitudes were checked against published maps and paper records on file. The analytical values reported within the dataset were also compared to paper records.

The geologic formation names of samples were then reclassified according to the standard stratigraphic code developed by the USGS and adopted and published by the Association of America Petroleum Geologists (AAPG) (Cohee, 1967, 1974). The AAPG standard stratigrahic code is used in the USGS Water Resource Division's ground-water information databases, and therefore geologic comparisons between rock and waterchemistry could be easily made between rock and groundwater databases. 


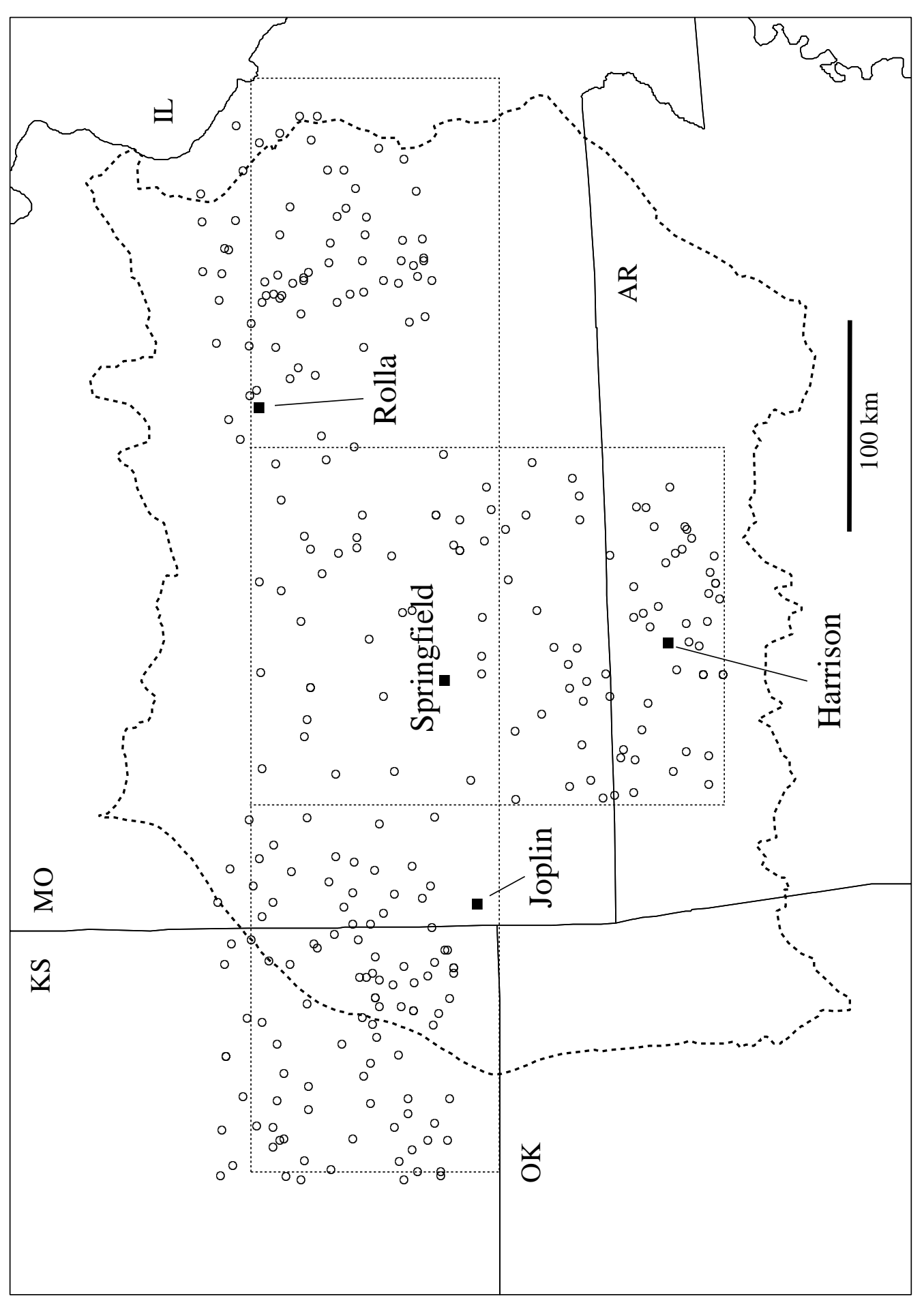

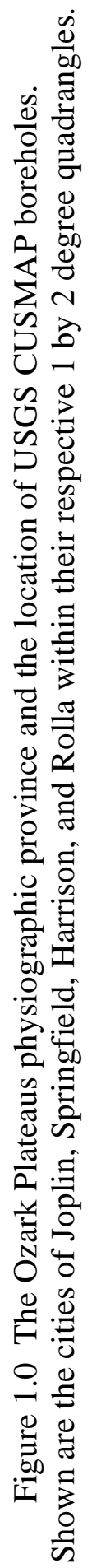




\section{THE SPATIAL DISTRIBUTION OF MVT-RELATED METALS ROCKS OF THE OZARK REGION}

The spatial distribution of MVT-related metals in rocks was investigated through 2-D mapping and 3-D geologic modeling. The following sections discuss these methods.

\section{TWO-DIMENTIONAL MAPS OF THE CONCENTRATIONS OF METALS IN OZARK REGION ROCKS}

Figures 2.0 through 2.7 show the 2-D spatial distribution of $\mathrm{As}, \mathrm{Cd}, \mathrm{Co}, \mathrm{Cu}, \mathrm{Cr}, \mathrm{Ni}$, $\mathrm{Pb}$ and $\mathrm{Zn}$ in the acid-insoluble residues of rock samples. The figures are elementalconcentration maps that show the sites at which MVT-related metals were detected in insoluble residues.

\section{INTERPRETATIONS OF 2-D MAPS}

In general, elevated concentrations of MVT metals in rocks form trends that coincide with the major structural zones of the Ozark region. Elevated concentrations of MVT metals are associated with the St. Francois Mountains, Central-Missouri Tectonic Zone, Bolivar-Mansfield Tectonic Zone, and the Chesapeake Tectonic Zone.

High $\mathrm{Zn}$ concentrations (up to 10,000ppm) are clustered within the northern-Arkansas Chesapeake Tectonic Zone (Figure 2.7). High Cd concentrations (up to 500ppm) are also associated with this area (Figure 2.1). Cd is the most abundant minor constituent of Ozark region sphalerite (Hagni, 1983), and the correlation of $\mathrm{Zn}$ and $\mathrm{Cd}$ in this area suggests that sphalerite may make up a significant proportion of insoluble residues. Binocular examinations of the insoluble residues tend confirm this; residues with high $\mathrm{Zn}$ and Cd content commonly contain visible sphalerite (R. Erickson, unpub. data).

High $\mathrm{Pb}$ concentrations (2000ppm) occur scattered throughout the Ozark region, but are consistently higher along structural trends (Figure 2.6). Many sites with high $\mathrm{Pb}$ are also high in As (Figure 2.0). Clusters of high $\mathrm{Pb}$ and As concentrations are associated with the southern extent of the Bolivar-Mansfield Tectonic zone and the northern-Arkansas Chesapeake Tectonic Zone. Very high Cu concentrations (>7000ppm) occur scattered throughout the Ozark region (Figure 2.4). Co, Cr, and Ni distributions show that these metals are frequently detected low concentrations (Figures 2.2, 2.3, 2.5). However, throughout the Ozarks high concentrations of $\mathrm{Co}, \mathrm{Cr}$, and $\mathrm{Ni}$ are associated with the major structural zo nes of the Ozark region. 


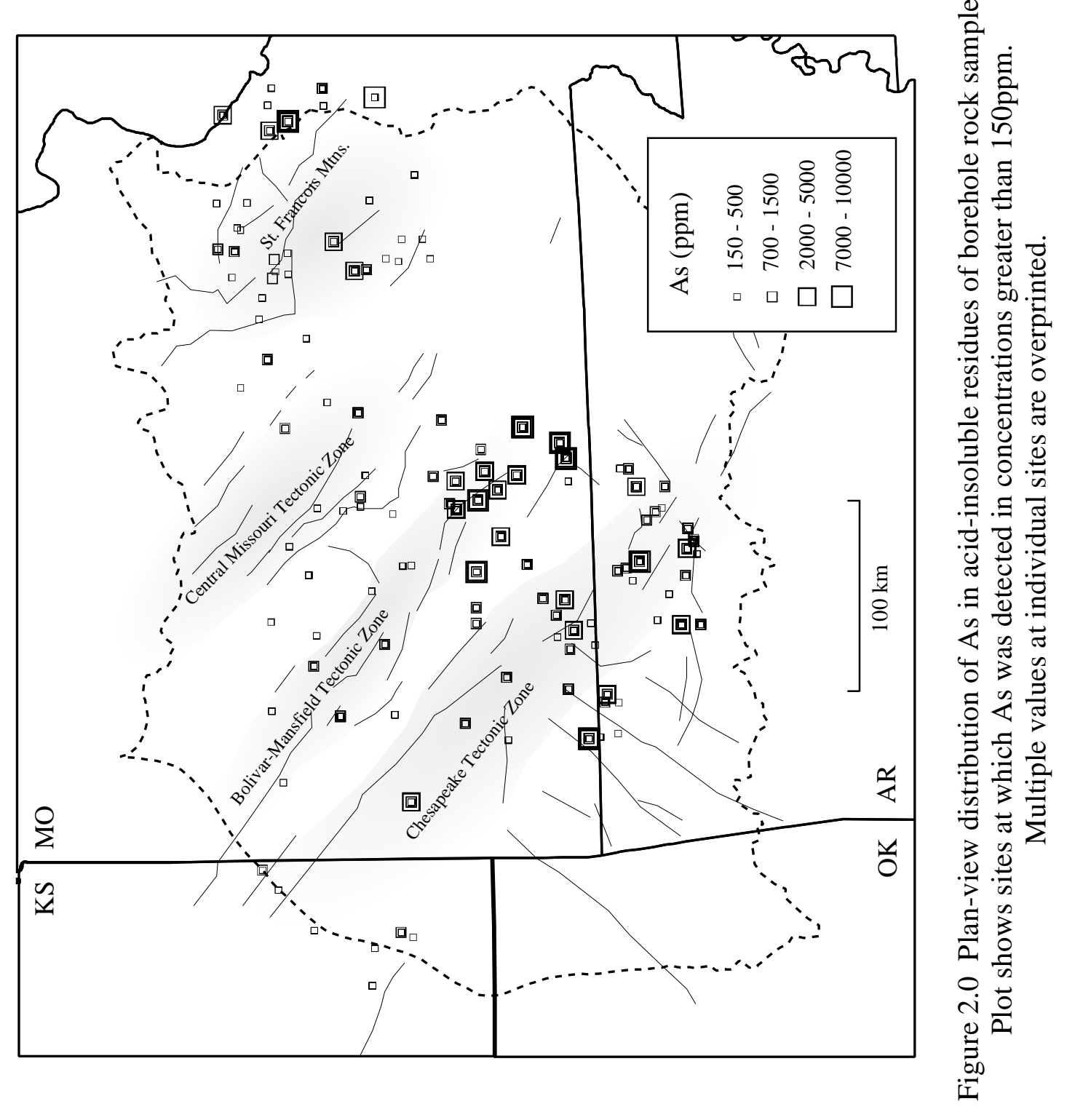




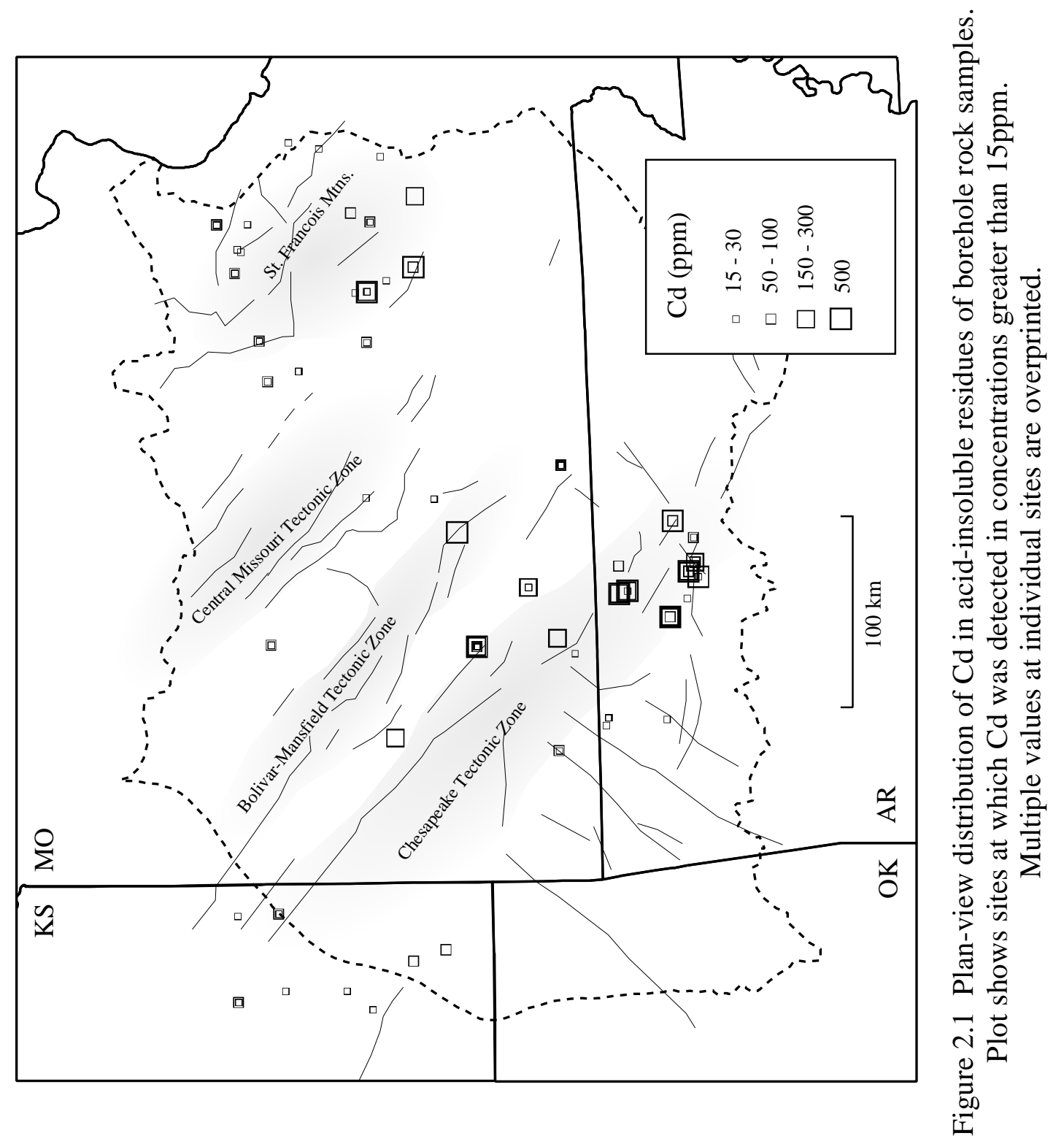




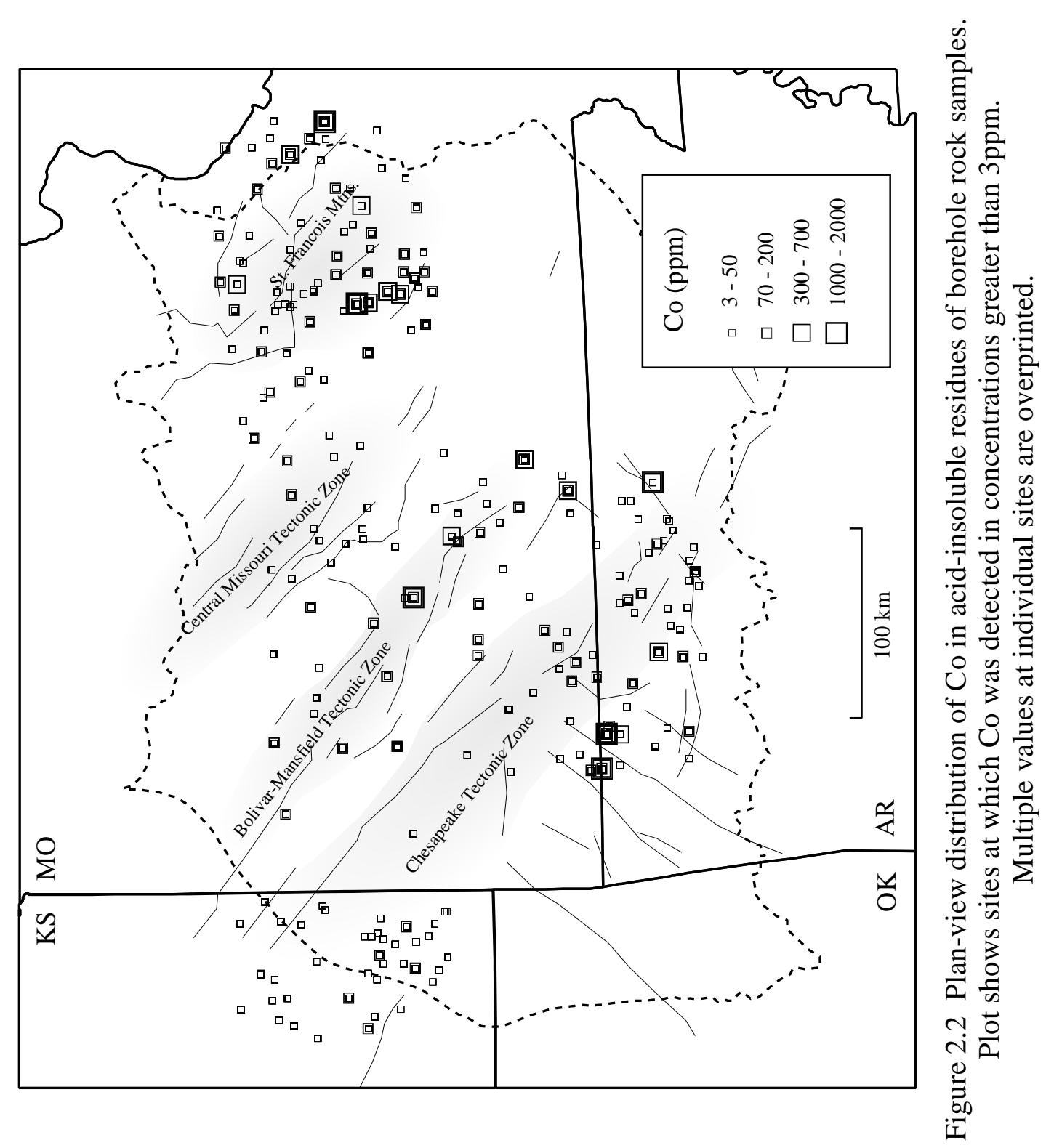




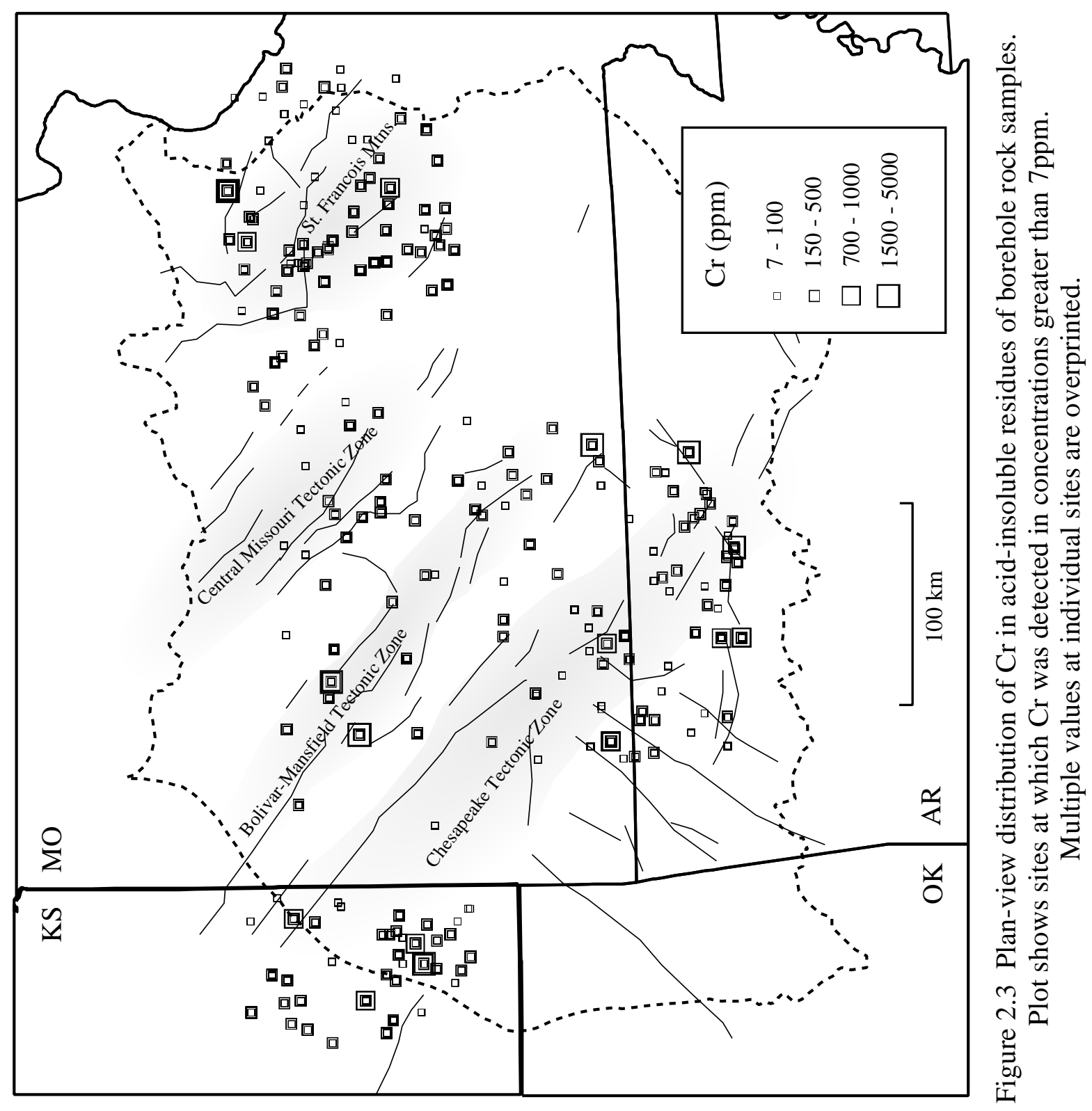




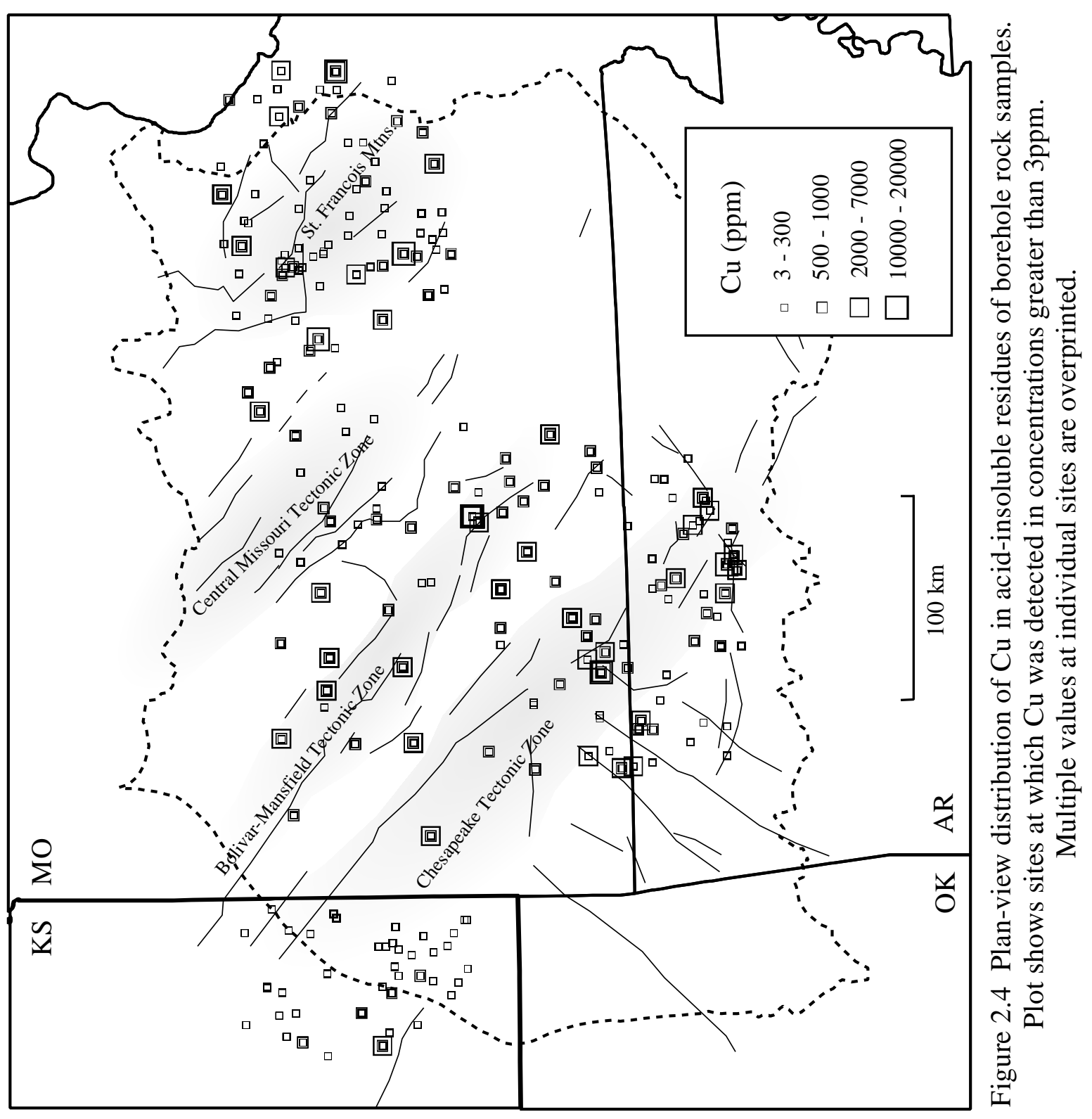




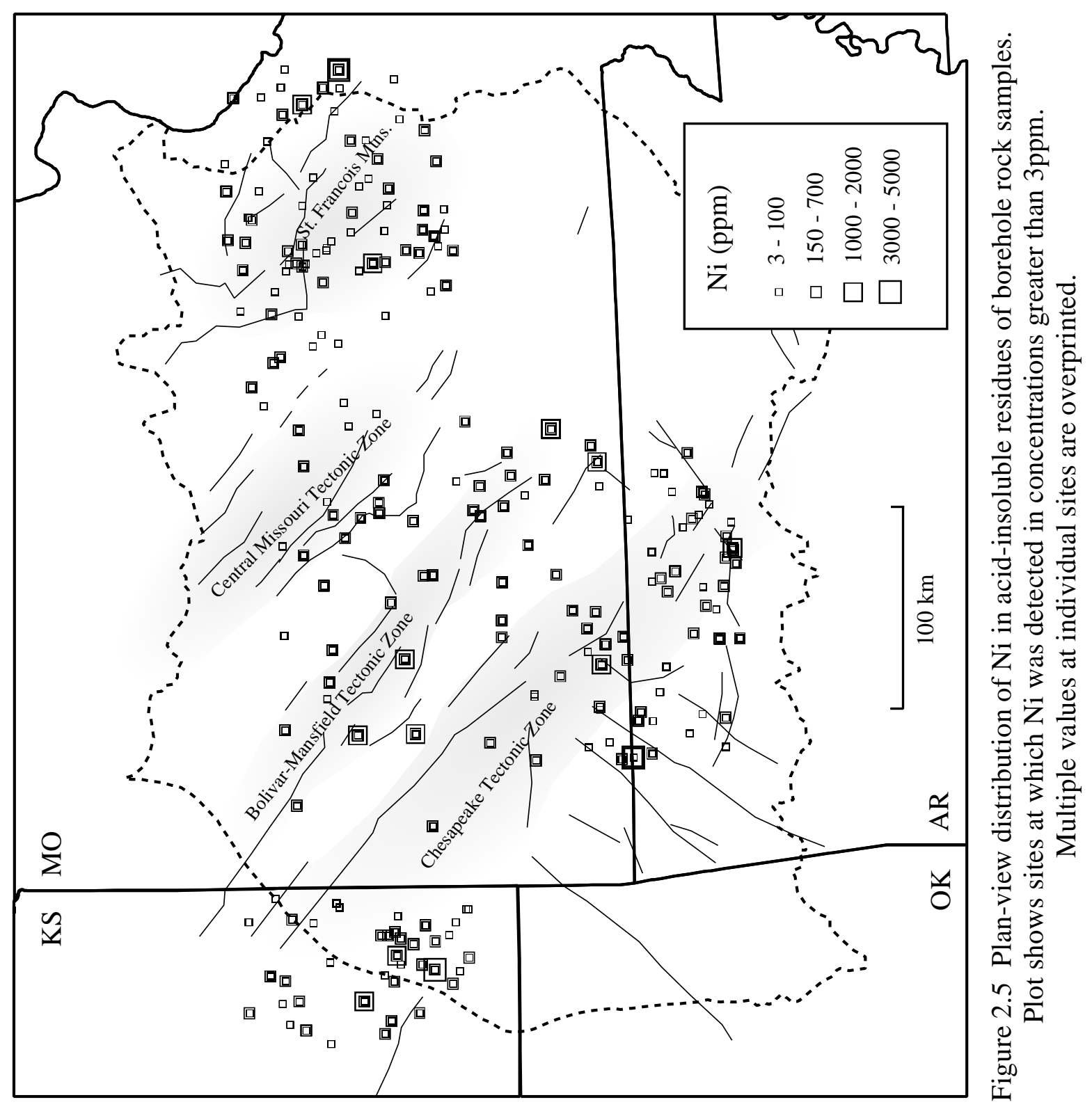




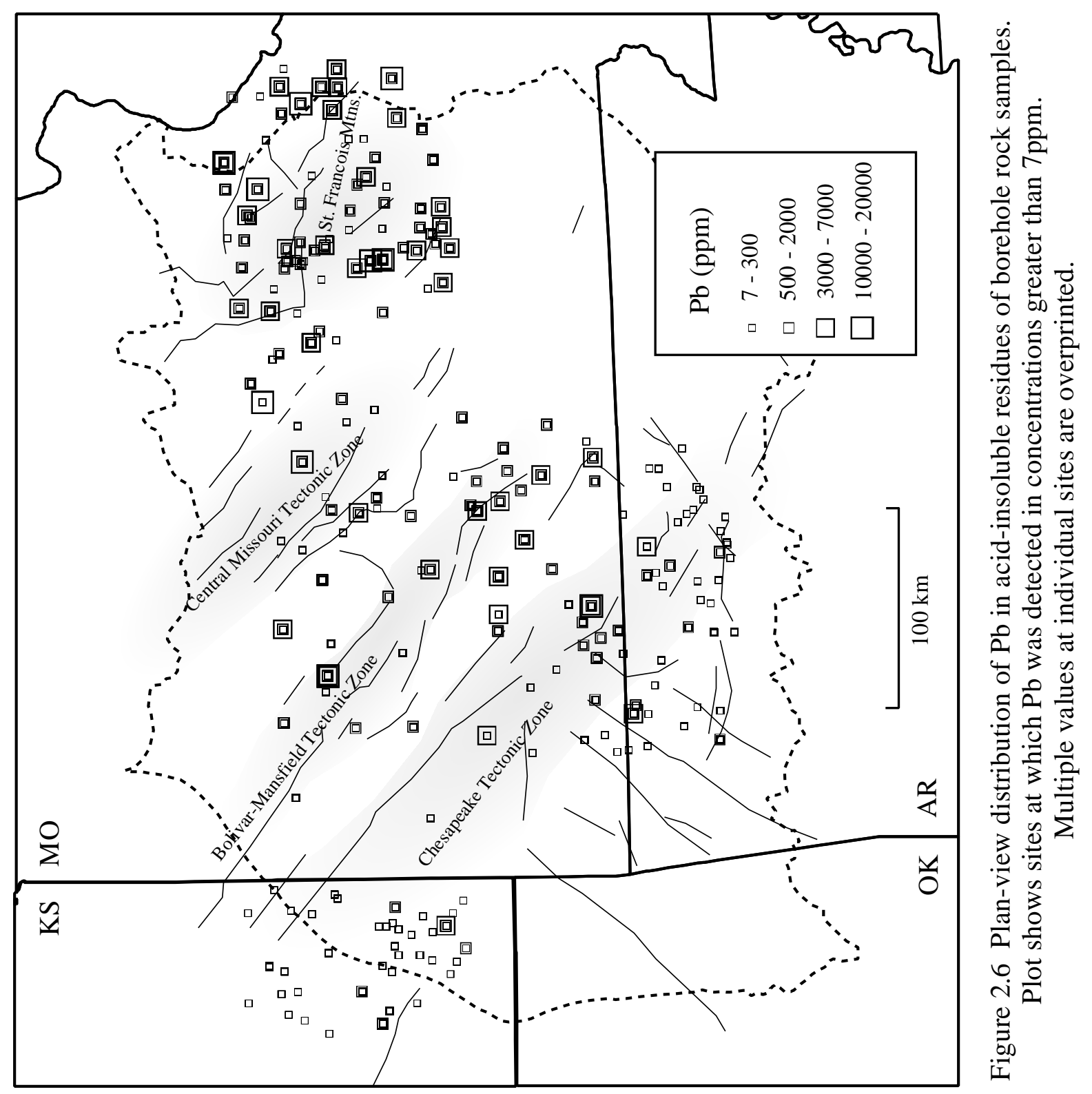



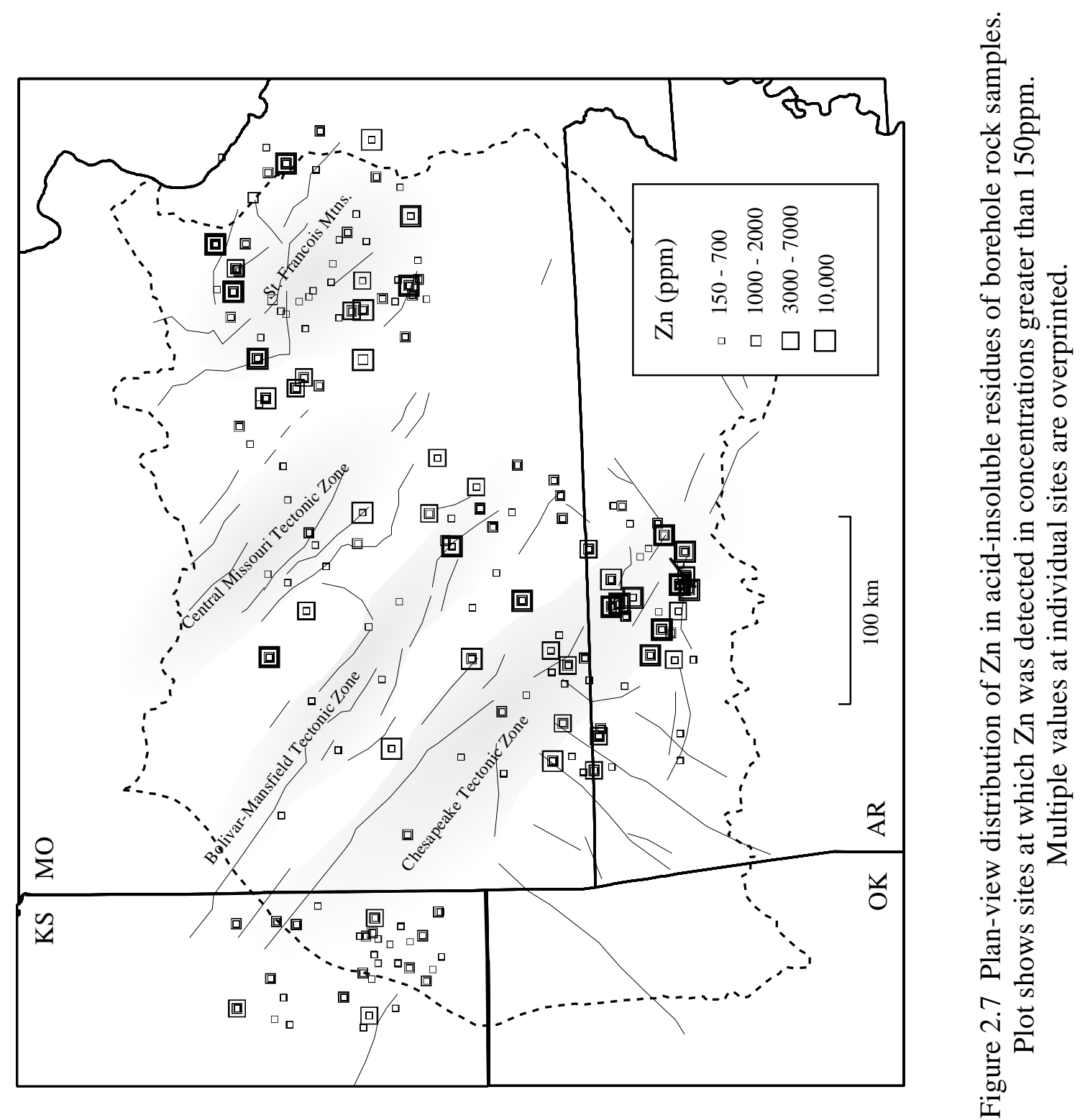


\section{THREE-DIMENSIONAL VISUALIZATIONS OF THE CONCENTRATIONS OF METALS IN ROCKS OF THE CENTRAL OZARKS REGION}

The spatial occurrence of MVT-related metals was also investigated through 3-D geologic modeling. A 3-D hydrogeologic model of the central portion of the Ozark region was used to characterize the 3-dimentional distribution of metals within the context of hydrostratigraphy. The central Ozarks area was chosen for 3-D visualization because a significant dissolved-metal anomaly existed in groundwater of this area (Lee, 2000).

Figures 2.8 and 2.9 show the 3-D distribution of $\mathrm{Zn}$ and $\mathrm{Pb}$ within the hydrostratigraphy the Ozarks. Each figure is a 3-D cross-sectional view of the central portion of the Ozark Uplift. The surfaces of the model are the tops of the regional aquifers made semi-transparent. Vertical exaggeration is approximately 40x. The enlarged red blocks within the model are the locations of insoluble residues that contain greater than a specified cut-off concentration. Cut-off concentrations were used because they simplify the visualizations by reducing the number of points displayed, and therefore more clearly show where high concentrations of metals occur and their associated trends.

In this report, $\mathrm{Zn}$ and $\mathrm{Pb}$ are the only MVT metals displayed in 3-D figures. The 3-D distribution of other metals may be inferred from the 2-D maps of section 2.1.0, and the statistics of section 3.0.

\section{INTERPRETATION OF 3-D VISUALIZATIONS}

Figure 2.8 shows that the high concentrations of $\mathrm{Zn}$ in rocks of northern Arkansas (defined in Figure 2.7) occur in the upper Ozark aquifer unit. Specifically, high Zn concentrations occur in the near surface to surface rocks of southern Missouri/ northern Arkansas. Similar 3-D visualizations showed that $\mathrm{Cd}$ concentrations have distribution patterns almost identical to $\mathrm{Zn}$.

Figure 2.9 shows that the high $\mathrm{Pb}$ concentrations in rocks are also associated with the upper Ozark aquifer unit in the same area containing high $\mathrm{Zn}$ concentrations. However, overall, high $\mathrm{Pb}$ concentrations tend to occur lower in the section. For example, the high lead concentrations associated with the Bolivar-Mansfield Tectonic Zone (defined in figure 2.6) occur low in the hydrologic section of northern Arkansas/southern Missouri. The remaining MVT metals have 3-D distribution patterns similar to lead. 


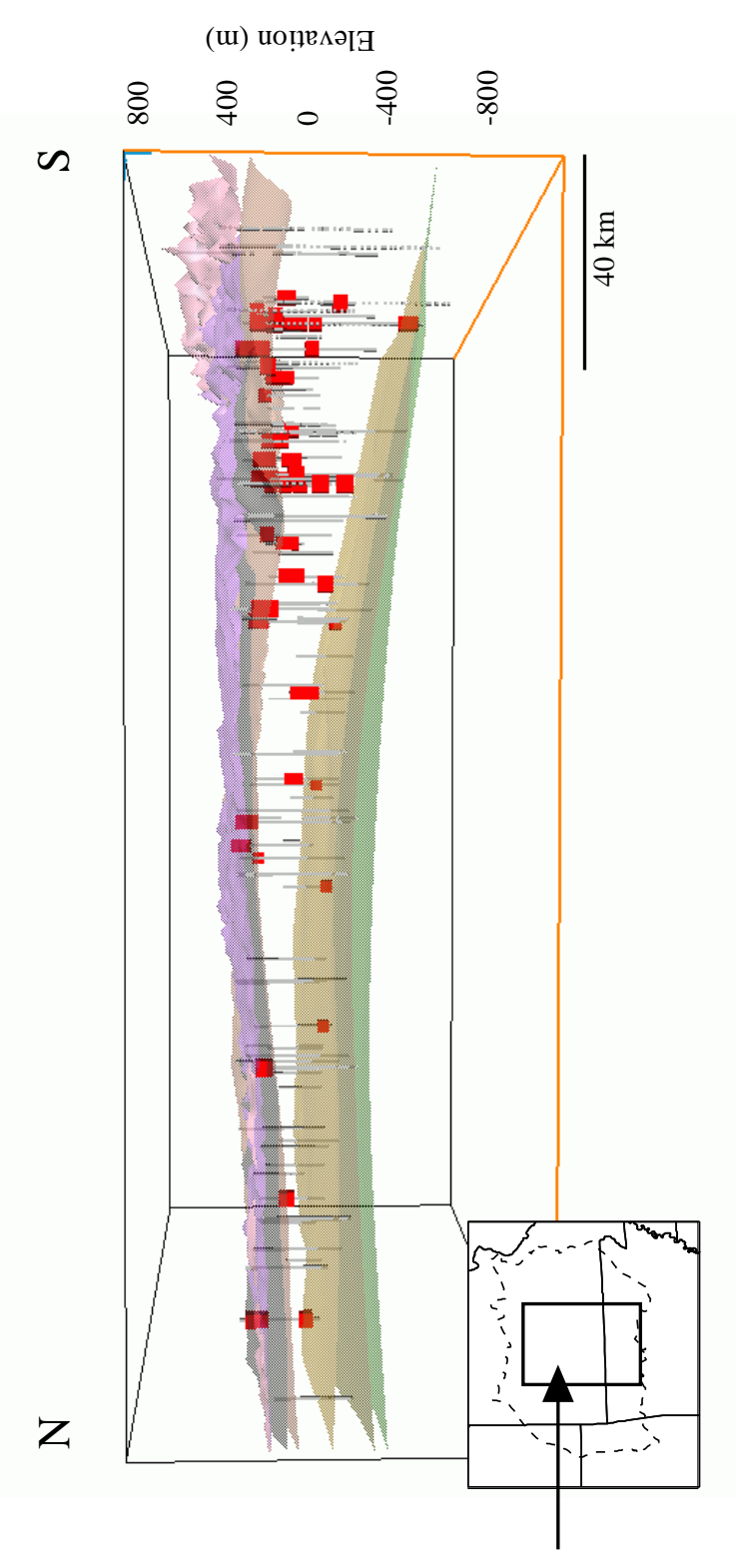

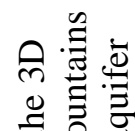

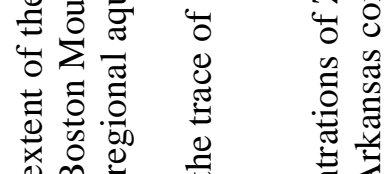

舟离

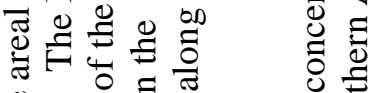

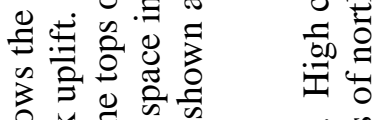

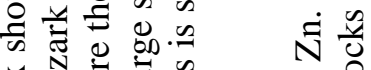

○ิ

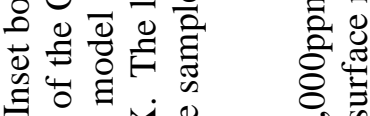

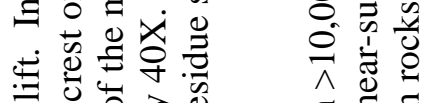

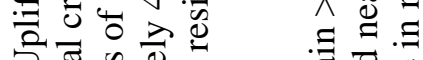

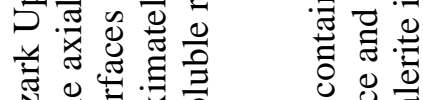

芯导志不

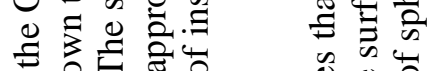

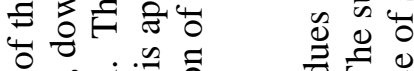

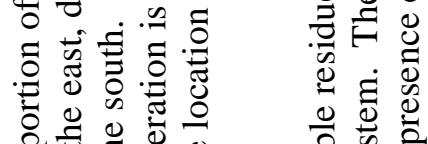

ส

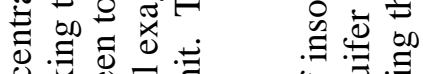

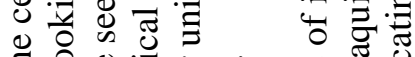

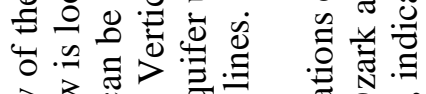

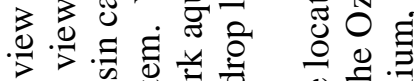

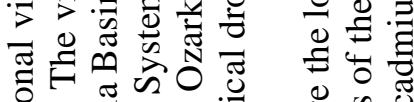

ड

论

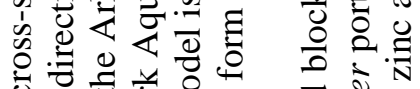

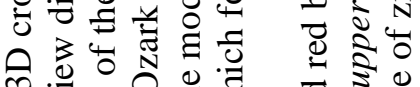

लि. $\frac{0}{7} 0$ O

i

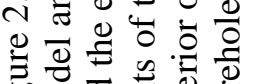

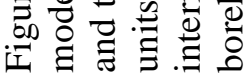

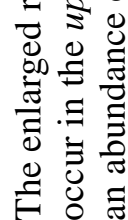



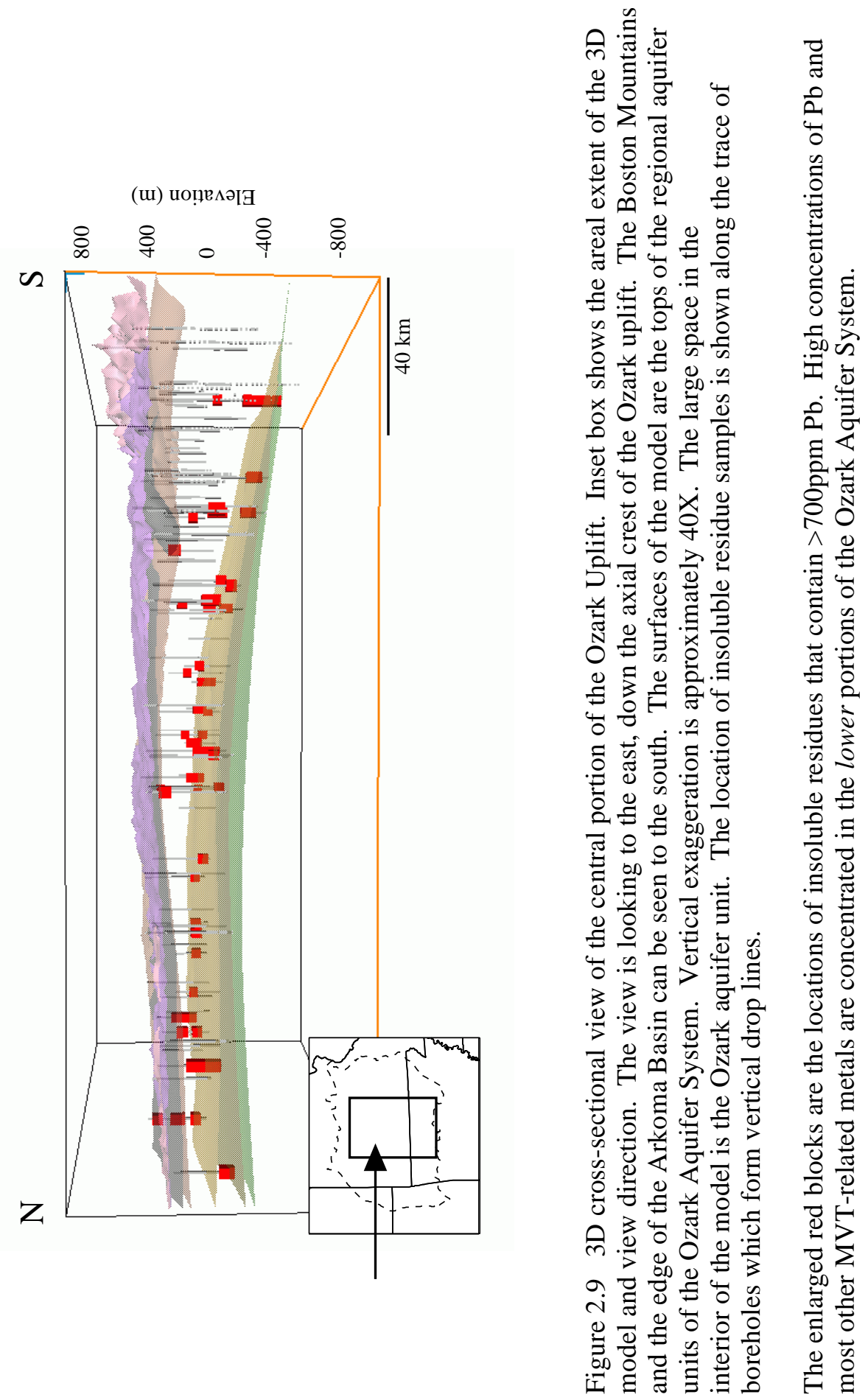


\section{THE STATISTICAL DISTRIBUTION OF MVT-RELATED METALS IN ACID- INSOLUBLE RESIDUES OF OZARK REGION ROCKS}

The statistical distribution of MVT-related metals by geologic and hydrologic unit was characterized through concentration-detection frequency grids. These grids are unique to this study and were designed to visually define the ranges and central tendencies of semiquantitative element concentrations throughout the stratigraphic column. They are a method of statistically describing semi-quantative determinations without transforming or reducing the original dataset. The following section describes the attributes and use of these grids.

\section{CONCENTRATION-DETECTION FREQUENCY GRIDS}

Table 1.0 is a generalized stratigraphic column of the Ozark Plateaus sedimentary section. Shown are the geologic and hydrogeologic units of the Ozark region along with their corresponding AAPG code. The AAPG code of geologic units is used as a formational key for the following concentration-detection frequency grids. Note that some samples were assigned to combined or undifferentiated formational codes and therefore, some units occupy more vertical space than others. Consequently, the verticality of the section does not correspond to relative stratigraphic thickness.

Tables 1.1 through 1.8 are frequency grids for $\mathrm{As}, \mathrm{Cd}, \mathrm{Co}, \mathrm{Cr}, \mathrm{Cu}, \mathrm{Ni}, \mathrm{Pb}$, and $\mathrm{Zn}$. The far left column of the grids are the sampled formations arranged in the general stratigraphic order that corresponds to that of Table 1.0. The bold horizontal lines of the grid between certain geologic formations delineate the boundaries of hydrogeologic units that are shown on Table 1.0

The uppermost row of the grids are the semi-quantitative concentration bins. The numbers within the colored cells of the grid are the total number of detections within a concentration bin for a given formational unit; in other words, these numbers represent the number of times an element-concentration was detected within a geologic formation. For example, in Table 1.1, within Pennsylvanian rocks (AAPG code $=320 \mathrm{PSLV}$ ) arsenic was detected once at a concentration of $150 \mathrm{ppm}$.

The last two columns on the far right of the grids show the total number of times an element was detected within a geologic unit, and the total number of samples representative of a geologic unit. These columns display the overall stratigraphic occurrence of metals and can serve as an aid in making cross-formational comparisons.

As a visual aid, the total distribution of frequency values, for each element, was logarithmically color scaled. The total distribution of frequencies, and assigned color codes is displayed below the grid. In summary, darker colors within the concentration-detection frequency grids represent a higher frequency of detections (higher frequency of metal occurrence), while the lighter colors represent lower frequencies of detection (lower frequency of metal occurrence). Approximate 
concentrations modes for each formation are defined by a horizontal clustering of darker cells.

\section{INTERPRETATION OF THE CONCENTRATION-DETECTION FREQUENCY GRIDS}

Tables 1.1 through 1.8 show that high-concentration detections of MVT metals occur most frequently lower in the section, specifically within Cambrian rocks of the lower Ozark aquifer unit and St. Francois aquifer and confining units. In these aquifer units, the Potosi and Eminence Dolomites, the Derby-doerun, and the Bonnterre Formation host the highest concentrations and occurrences of metals.

$\mathrm{Zn}$ and $\mathrm{Cd}$ are exceptional in their distribution. High concentrations of $\mathrm{Zn}$ and $\mathrm{Cd}$ are detected most frequently in the upper Ozark aquifer unit and the Springfield Plateau aquifer unit. Within the upper Ozark aquifer unit, the Everton Formation, St. Peter Sandstone, and Jefferson City-Cotter \& Powell dolomites contain high concentrations of $\mathrm{Zn}$ and $\mathrm{Cd}$. In the Springfield Plateau aquifer unit, the Boone Formation hosts high concentrations of $\mathrm{Zn}$ and $\mathrm{Cd}$. 


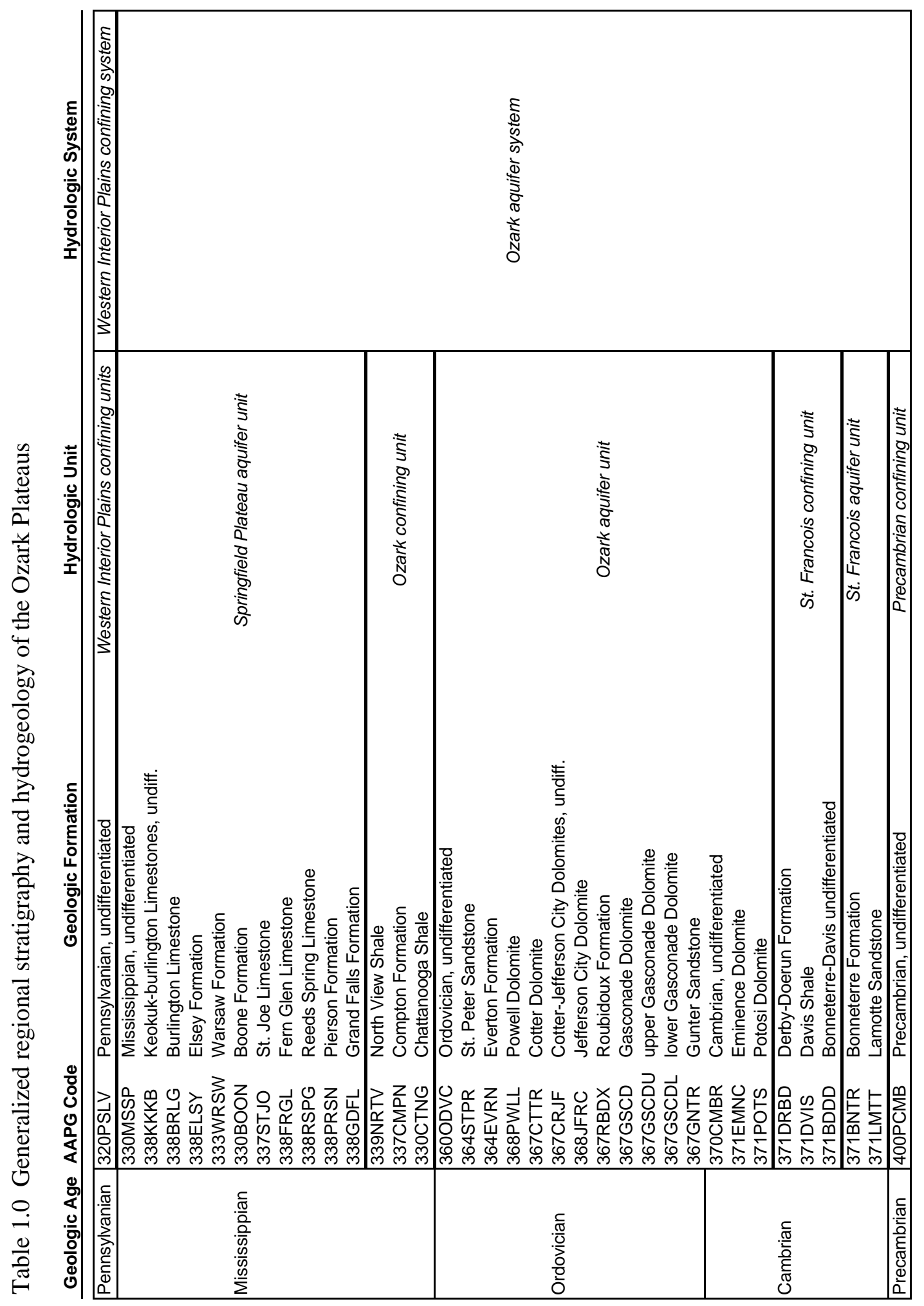




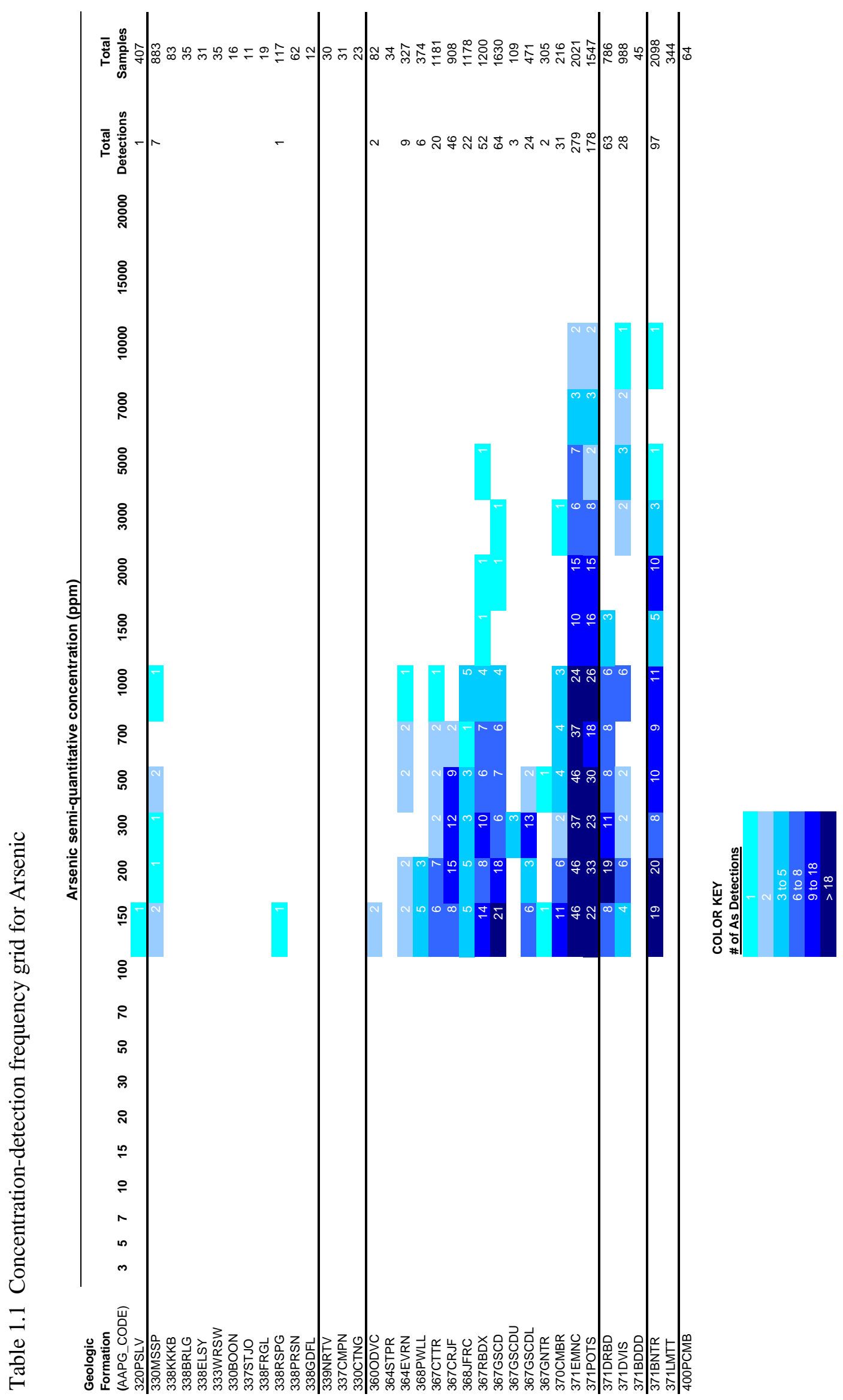




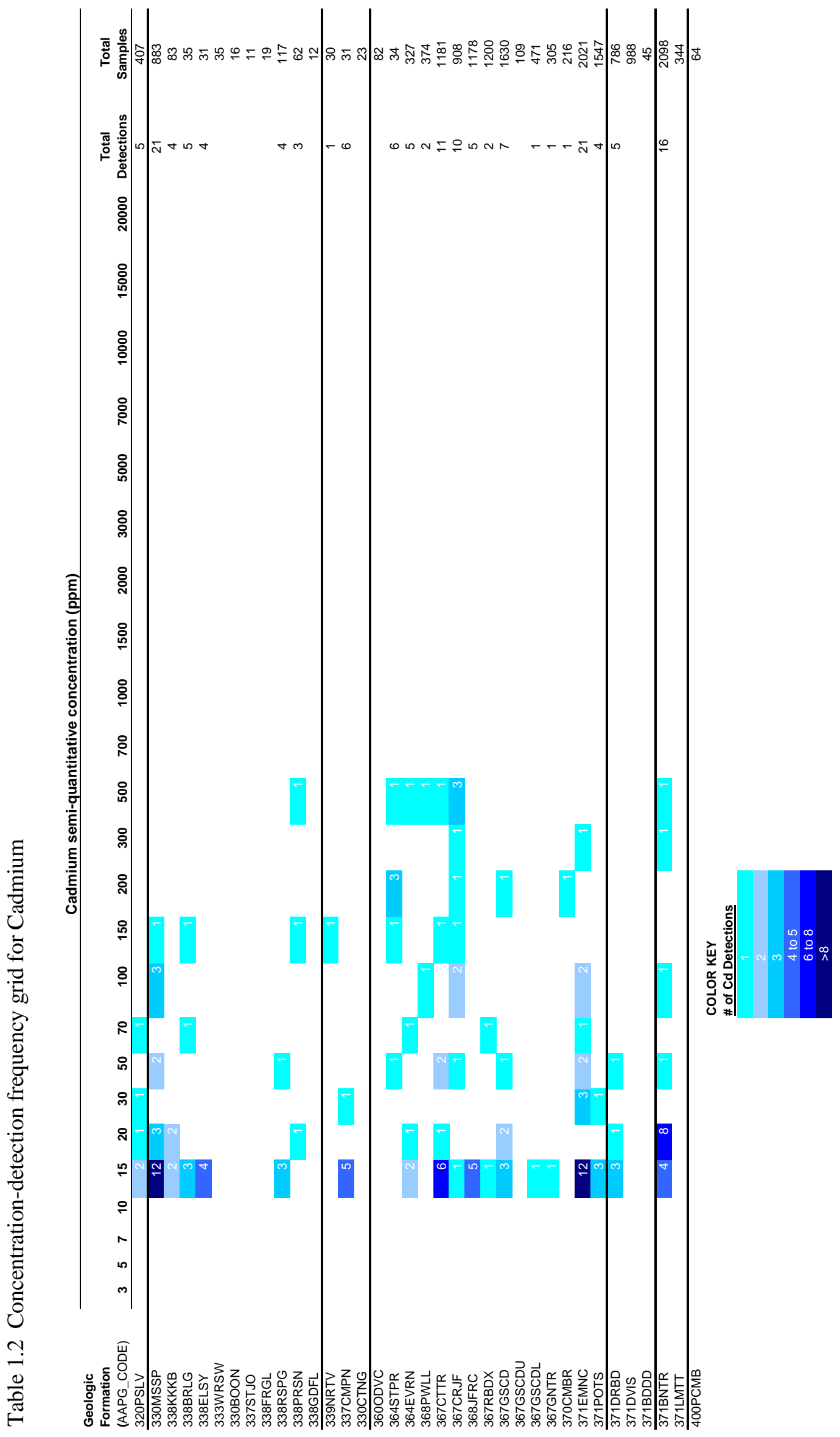




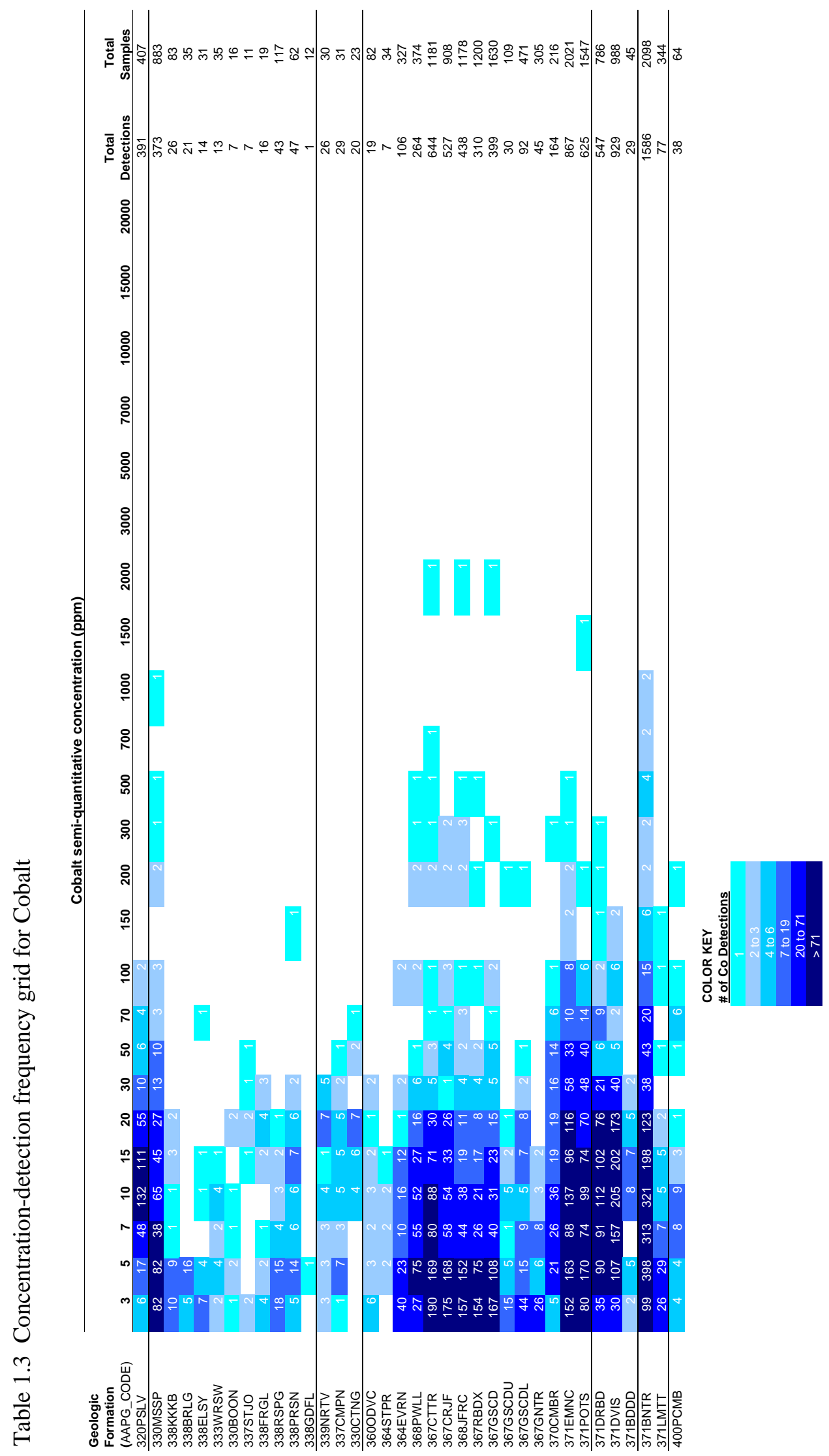




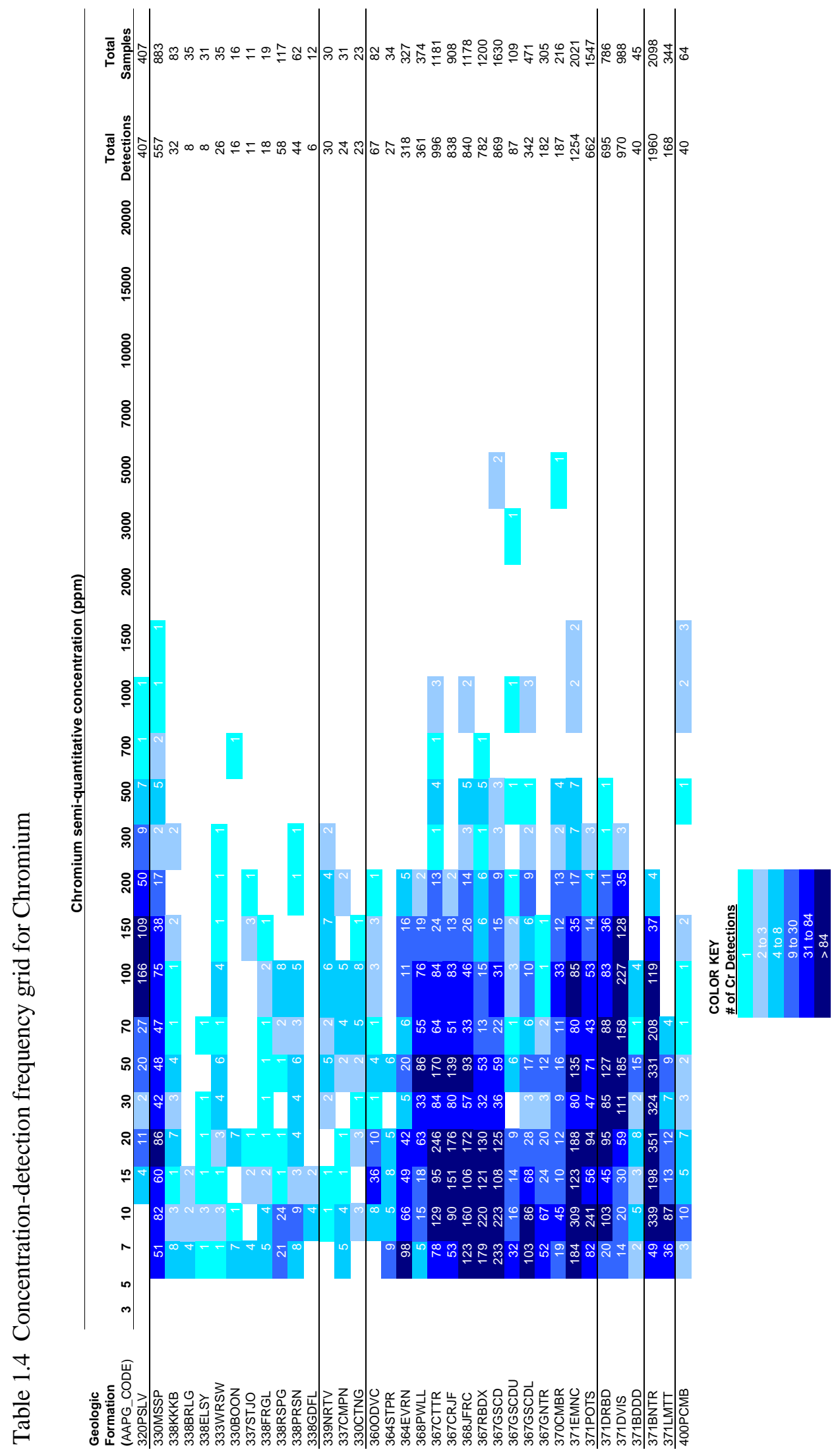




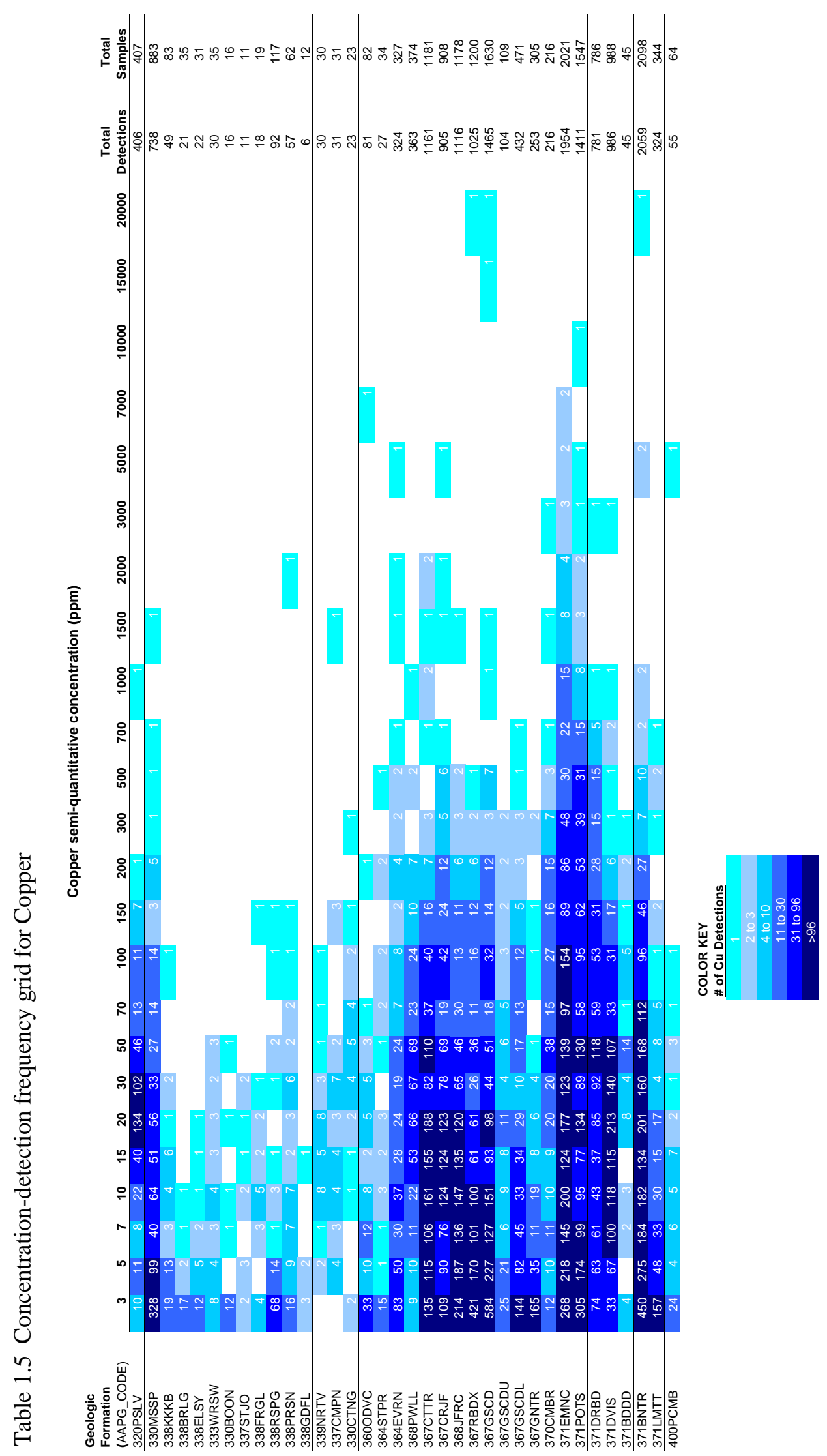




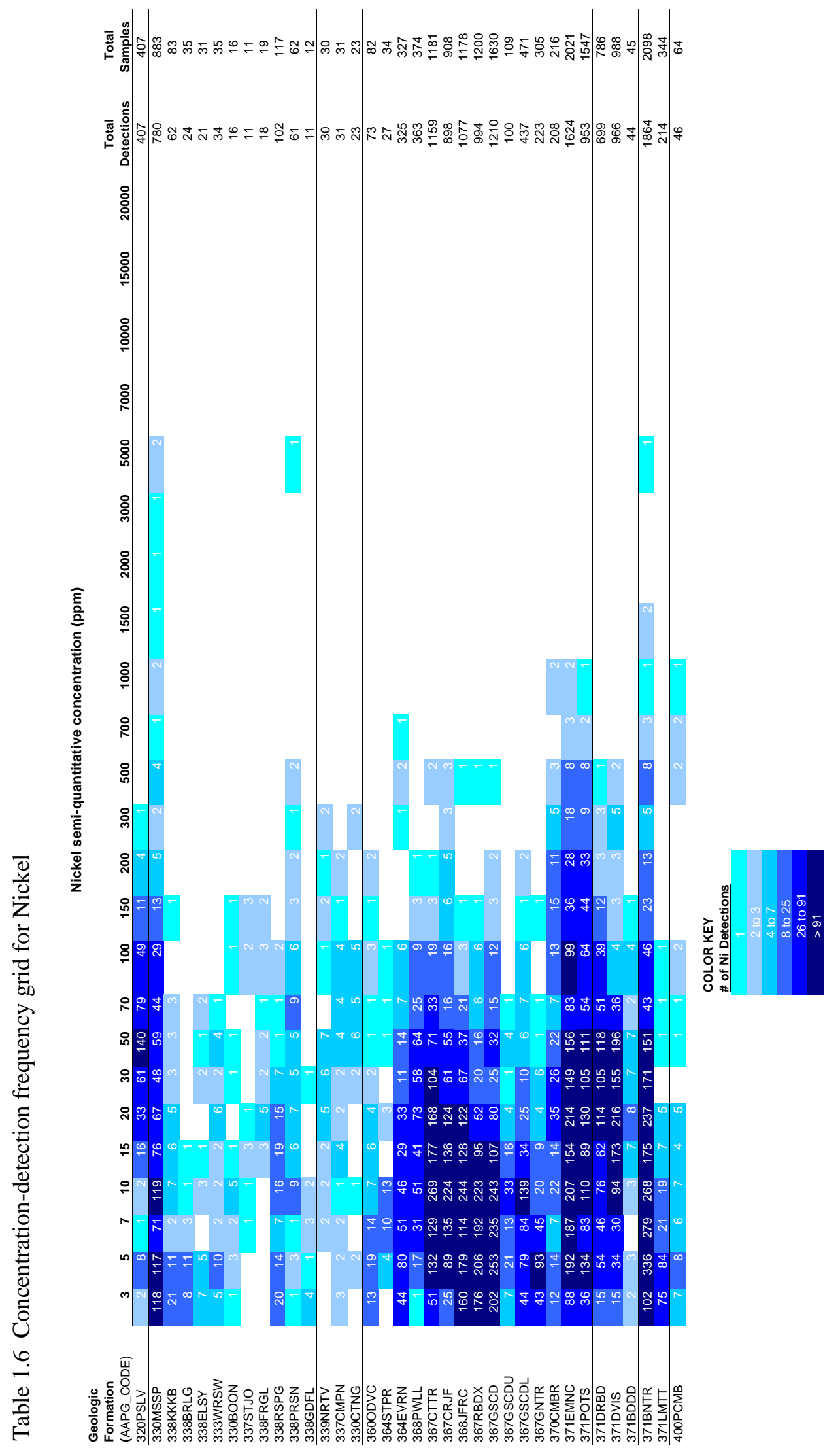




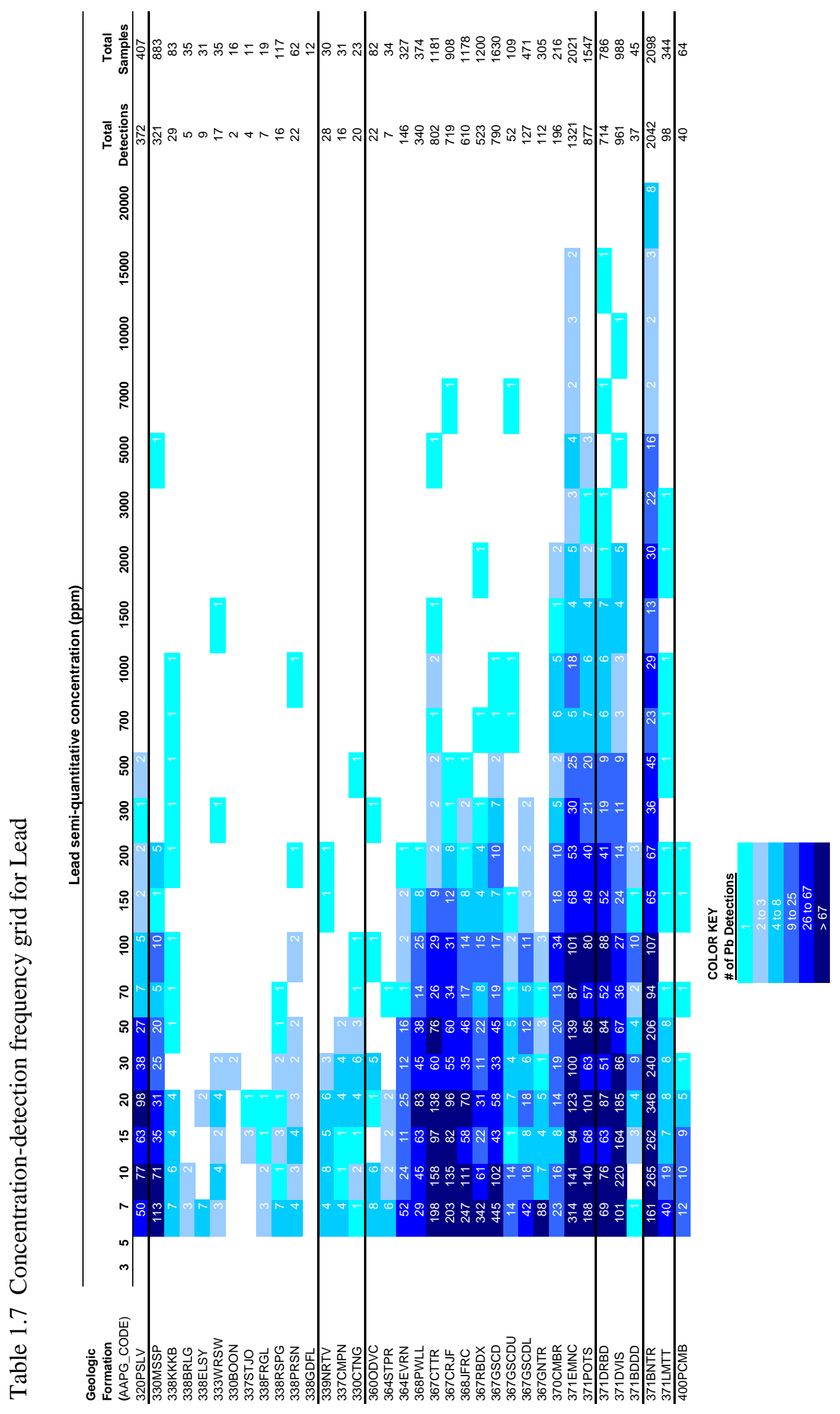




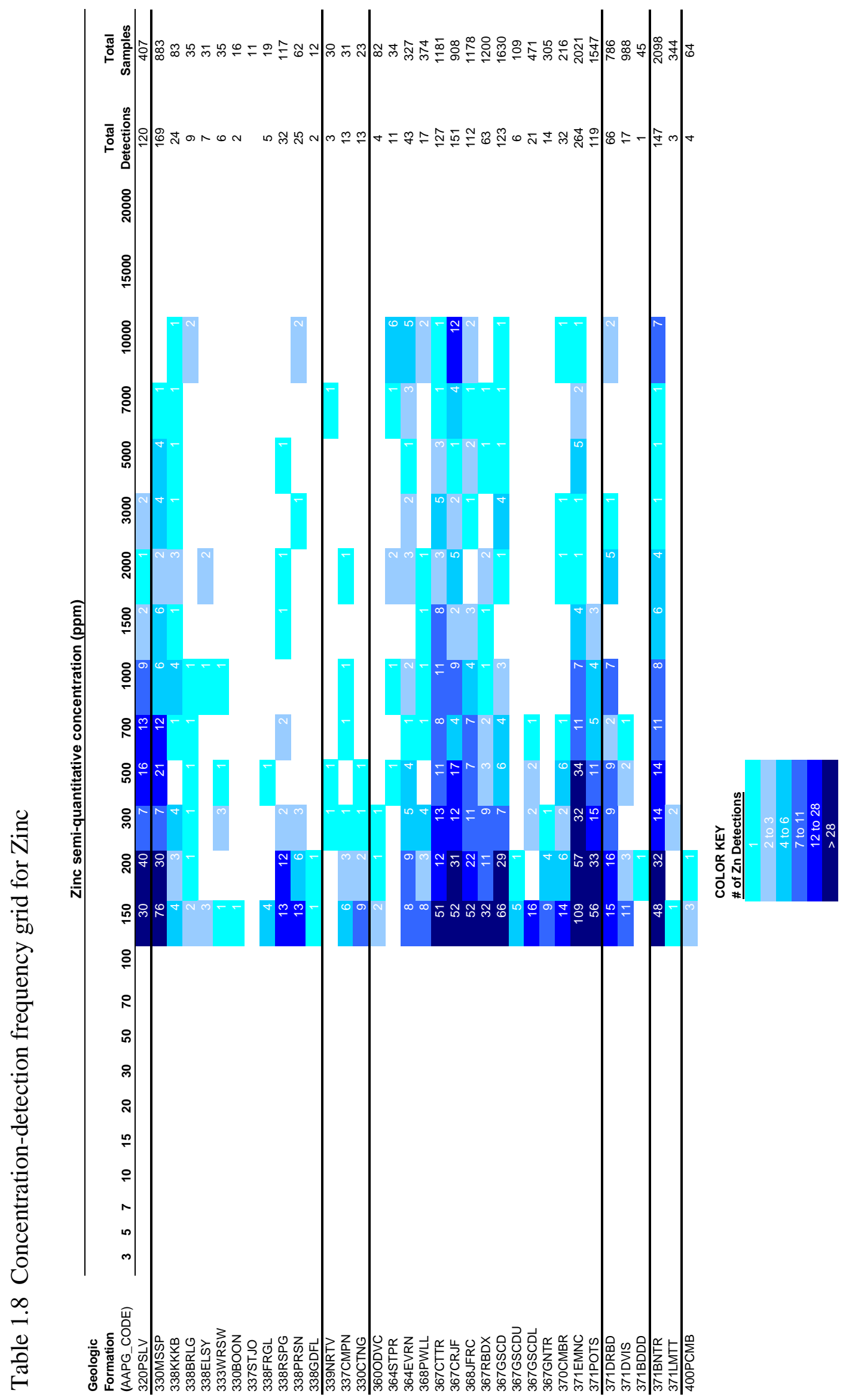




\section{REFERENCES CITED}

Cohee, George V. (1967) Standard stratigraphic code adapted by the AAPG. American Association of Petroleum Geologists Bulletin, v.51, no. 10, pp2146-2151.

Cohee, George V. (1974) U.S. Geological Survey computerizes stratigraphic names according to AAPG code. American Association of Petroleum Geologists Bulletin, v.58, no. 2, pp312-313.

Erickson R. L., Mosier E. L., and Viets J. G. (1978a) Generalized geologic and summary geochemical maps of the Rolla 1 x 2 degree quadrangle, Missouri. U. S. Geological Survey Miscellaneous Field Studies Map MF- 1004-A, pp. (1 sheet).

Erickson R. L., Mosier E. L., Odland S. K., and Erickson M. S. (1981) A favorable belt for possible mineral discovery in the subsurface Cambrian rocks in southern Missouri. Economic Geology 76, 921-933.

Erickson R. L., Mosier E. L., and Viets J. G. (1978b) Lithogeochemical studies in Missouri. In U. S. Geological Survey Professional Paper 1044-9612, pp. 9.

Erickson R. L., Erickson M. S., Mosier E. L., and Chazin B. (1985) Summary geochemical generalized geologic maps of the Springfield $1 \times 2$ degree Quadrangle and adjacent area, Missouri. U. S. Geological Survey Miscellaneous Field Studies Map MF-1830-A, pp. 53 (2).

Erickson R. L., Chazin B., and Erickson M. S. (1988a) Summary geochemical maps of the Harrison 1 x 2 degree Quadrangle, Arkansas and Missouri. U. S. Geological Survey Miscellaneous Field Studies Map MF-1994-A, pp. 57 (3 sheets).

Erickson R. L., Chazin B., Erickson M. S., Mosier E. L., and Whitney H. A. (1988b) Tectonic and stratigraphic control of regional subsurface geochemical patterns, Midcontinent, U.S.A. In North America conference on Tectonic control of ore deposits and the vertical and horizontal extent of ore systems (ed. G. Kisvarsanyi and S. K. Grant), pp. 435-446.

Erickson R. L., Mosier E. L., Folger H. W., Bullock J. H., Jr., Berendsen P., and Daly M. (1990) Summary geochemical maps of the Joplin 1 x 2 degree Quadrangle, Kansas and Missouri. U. S. Geological Survey Miscellaneous Field Studies Map MF-2125-A, pp. 82 (1 sheet). 
Erickson R. L. and Chazin B. (1991) Resource assessment for mississippi valley-type base-metal deposits. In Geology and mineral-resource assessment of the Springfield 1 X 2 degree Quadrangle, Missouri, as appraised in September 1985: U. S. Geological Survey Bulletin 1942 (ed. J. A. Martin and W. P. Pratt), pp. 9094.

Grimes D. J. and Marranzino A. P. (1968) Direct-current arc and alternating-current spark emission spectrographic field methods for the semiquantitative analysis of geologic materials, U.S. Geological Survey Circular 591 6p.

Hagni R. D. (1983) Minor elements in Mississippi valley-type ore deposits. In Cameron symposium on unconventional mineral deposits (ed. W. C. Shanks, III), pp. 71-88

Lee, Robert C. Lopaka (2000) The effect of Mississippi Valley-Type mineralization on the natural background chemistry of groundwater in the Ozark Plateaus region of the United States. Unpublished Master's thesis, Colorado School of Mines, Golden, CO, United States.

Martin J. A. e. and Pratt W. P. e. (1991) Geology and mineral-resource assessment of the Springfield 1x2 degree quadrangle, Missouri, as appraised in September 1985, U. S. Geological Survey Bulletin 1942 pp. 115 (1 map). 